\title{
Staphylococcus aureus isolates from bovine subclinical mastitis in central Ethiopia revealed the presence of antimicrobial resistance and resistant genes
}

Desiye Tesfaye Tegegne ( $\boldsymbol{\nabla}$ desiye.tegegne@gmail.com )

Ethiopian Institute of Agricultural Research https://orcid.org/0000-0003-3722-6743

Gezahegne Mamo

Addis Ababa University

Hika Waktole

Addis Ababa University

Gebrerufael Girmay

Ethiopian Institute of Agricultural Research

Research

Keywords: Antimicrobial susceptibility, Antimicrobial resistance gene, bovine mastitis, Central Ethiopia, Staphylococcus aureus

Posted Date: March 26th, 2021

DOI: https://doi.org/10.21203/rs.3.rs-361426/v1

License: (c) (i) This work is licensed under a Creative Commons Attribution 4.0 International License.

Read Full License 


\section{Abstract}

Background: Staphylococcus aureus is one of the predominant causative agents of mastitis disease in dairy herds. Mastitis disease has a negative impact in the economic losses in the dairy sector across the globe. The aims of this study were to determine the prevalence and detect antimicrobial resistance genes in the Staphylococcus aureus isolated from milk samples of subclinical bovine mastitis in Central Ethiopia.

Methods: A total of 265 lactating dairy cows from various dairy farms in four different geographical locations were screened by California mastitis test (CMT) for bovine subclinical mastitis. One-hundred thirty CMT positive milk samples were collected and transported to laboratory. Different biochemical tests and polymerase chain reaction (PCR) were used for the identification of $S$. aureus isolates. Finally, phenotypic and genotypic methods were performed for detection of some antimicrobial resistance patterns and genes ( $m e c A, e r m A, e r m C$, and $m s r A)$, respectively.

Results: From total of 265 lactating dairy cows screened, $49 \%(n=130)$ were positive for bovine subclinical mastitis. One-hundred thirty mastitic milk samples were subjected to bacterial culturing, one hundred $(76 \%)$ S. aureus isolates were identified based on phenotypic characters. Sixty-eight confirmed $S$. aureus isolates were obtained using PCR. Of the sixty-eight isolates tested 12 samples were contained the methicillin resistance gene $\mathrm{A}(\operatorname{mec} \mathrm{A})$. No amplification was observed for the erythromycin resistance genes (ermA, ermC, and $m s r A)$.

Conclusion: The high resistance of Staphylococcus aureus to commonly used antimicrobials contribute in dairy farms may cause health problems in the community consuming raw milk purchased from these farms.

\section{Background}

Mastitis is a common disease of dairy cows and a major concern for the dairy industry because of economic losses due to decreased animal health and increased antibiotics usage (Heikkilä et al., 2018; Gussmann et al., 2019). Due to multiple etiologies, it always remained a challenge to veterinarian worldwide. Approximately, 140 species of microorganisms have been identified as etiological agents of bovine mastitis (Radostits et al., 2007). Of these various etiological agents, Staphylococcus aureus (S. aureus) is one of the major agents of contagious mastitis, responsible for mainly bovine subclinical and clinical infections in cattle worldwide (Barkema et al., 2006). This pathogen, in combination with both the bovine host and environmental factors, is characterized by low cure rates compared with other mastitis pathogens because of its capability to acquire antibiotic resistance and produce a wide array of virulence factors (Gao et al., 2012).

Programs for mastitis prevention and treatment use wide range of antimicrobials (Wald et al., 2019). The indiscriminate use of antibiotics has led to the development of multiple antibiotic resistances thereby rendering the antibiotic treatment ineffective (Alian et al., 2012). The resistant bacteria present in 
environments are in contact with human beings and animals (Hu et al., 2017). Antimicrobial resistance is a major public health concern in many countries due to the persistent circulation of resistant strains of bacteria in the environment and the possible contamination of water and food (Gelbrand et al., 2015). Therefore, investigation of a wide spectrum of antimicrobial resistance genes of $S$. aureus isolated from cows with mastitis is crucial not only for bovine mastitis control, but also for public health (Xavier et al., 2017; Kadlec et al., 2019).

Although $S$. aureus responds poorly to treatment with many different antimicrobial agents, antibiotic therapy still plays a significant role in the prevention and cure of bovine Staphylococcal mastitis (Wald et al., 2019). The infection of cows with increasingly antibiotic-resistant strains can cause several therapeutic problems and is one of the main reasons for monitoring drug resistance (Saini et al., 2013). The measurement of $S$. aureus antimicrobial resistance using phenotypic susceptibility tests, such as disk diffusion, is essential in order to select the most appropriate and efficient therapy (Walker, 2006). These methods can be combined with molecular analysis, as phenotypic $S$. aureus resistance to the most commonly used antimicrobials is related to the expression of antibiotic-resistance genes (Cockerill, 1999).

Rapid methods for accurate detection and susceptibility determination of $S$. aureus isolates are necessary to minimize patient suffering by identifying the antimicrobial agents to which the isolated strains may be sensitive to and hence provide treatment options (Duarte et al., 2015). Owing to the poor discriminatory power of the phenotypic techniques, deoxyribonucleic acid (DNA) based identification and genotyping techniques are now considered the ideal methods for the detection of antimicrobial resistance genes of S. aureus (Perez-Roth et al., 2001; Song et al., 2015). In previous study that was conducted in Ethiopia, $S$. aureus isolates were identified using only the phenotypic antimicrobial susceptibility test and identification of S. aureus (Duguma et al., 2014; Marama et al., 2016). Presently, there are limited published studies conducted in central highland of Ethiopia concerning molecular characterization of antimicrobial resistance of $S$. aureus in dairy farms. Therefore, the aim of this study was to determine antimicrobial resistance (AMR) patterns of $S$. aureus isolated from bovine subclinical mastitis in central highland of Ethiopia.

\section{Methods}

\section{Study areas}

This study was conducted in selected areas of central Ethiopia including Adaberga, Ambo, Bishoftu and Holeta as indicated in Fig. 1. The areas were purposively selected based on the abundance of dairy farms that constituting the known milk sheds to the Addis Ababa, and based on their agro-ecological differences.

\section{Study Design And Study Population}

A cross sectional study design was employed to determine the prevalence, antimicrobial resistance and resistant genes of $S$. aureus from bovine subclinical mastitis in central highland of Ethiopia from October 
2018 to May 2019. The study population were lactating exotic Zebu cross-breed dairy cows which had not treated for mastitis either intra-mammary or systemic route during the study period. All dairy farms with herd size ranging from 20-110 cows, which were managed under semi intensive or intensive management system, were included as study population inclusion criteria.

\section{Sample Collection And Transportation}

The mastitis milk samples were taken from CMT positive dairy cows and collected according to earlier protocol (Quinn et al., 2004). Briefly, quarters were washed with tap water and dried with clean towel. The teat ends were then cleaned with cotton soaked with $70 \%$ ethyl alcohol. Then, after discarding the first three streams of milk, $10 \mathrm{ml}$ milk was collected aseptically into a sterile screw-cupped, pre-labeled test tube, by holding it in inclined position, so that, the pathogen that going to be recovered come from mammary gland. Finally, milk sample was held in an ice box for transportation to respective laboratory (National Agricultural Biotechnology Research Center, Holeta, Ethiopia) for isolation and identification of bacteria from milk samples. The samples were immediately cultured or stored at $4^{\circ} \mathrm{C}$ for a maximum of $24 \mathrm{hr}$ until cultured on standard bacteriological media.

\section{Bacterial Isolation And Identification}

Isolation and identification of $S$. aureus isolates were performed using the technique described beforehand (Quinn et al., 2015). Briefly, all samples were first inoculated onto freshly prepared nutrient agar (HiMedia, India) and incubated at $37^{\circ} \mathrm{C}$ for 24 hours. Bacterial colonies were identified based on colonial morphology, cultural characteristics, Gram's staining and biochemical tests. Staphylococcus aureus produces golden colonies on nutrient agar; it is non-motile; coagulase positive, catalase positive, ferments mannitol and produces double pattern of haemolysis on sheep blood agar. The isolates that were suspected to be Staphylococcus species were again sub-cultured onto freshly prepared Mannitol salt agar (MSA) (HiMedia, India) and incubated at $37^{\circ} \mathrm{C}$ for 24 hours. Golden yellow colonies were presumptively identified as $S$. aureus. Furthermore, a single golden yellow colony from the culture plate was sub-cultured on freshly prepared nutrient agar slants at $37^{\circ} \mathrm{C}$ for 24 hours, after which the slants were stored in the refrigerator for further analysis.

\section{Bacterial DNA Extraction}

Each isolate was inoculated into Brain Heart Infusion (BHI, Hampshire, UK) broth and incubated at $37^{\circ} \mathrm{C}$ for $24 \mathrm{hr}$. Aliquots of each culture were centrifuged and the supernatant was discarded. The pellet was used to extract DNA using Wizard $\circledast$ Genomic DNA extraction Kit (Promega Corporation, Madison, USA), according to manufacturer's instructions. Extracted DNA was quantified at 260/280 nm by Nanodrop (Thermo Fisher Scientific, Germany) and stored at -20 ॰C for further molecular work.

\section{Molecular conformation of Staphylococcus aureus}


Reference primers (Integrated DNA Technologies (IDT), San Diego, USA) Sau234 (F) (5'CGATTCCCTTAGTAGCGGCG-3') and Sau1501 (R) (5'-CCAATCGCACGCTTCGCCTA-3 ') targeting the 23SrRNA gene (Gene bank database $S$. aureus, GI no. 288516) were used to amplify the 23SrRNA gene, as previously described (Riffon et al., 2001). The primers (20 pmol) used in this study generated an amplicon of $1267 \mathrm{bp}$ as visualized by gel electrophoresis (CBS Scientific, United Kingdom). The PCR reaction volume was $25 \mu \mathrm{l}$ and consisted of $12.5 \mu \mathrm{l} 2$ x PCR master mix (Promega Corporation, Madison, WI, USA), $1 \mu$ l forward primer, $1 \mu$ l reverse primer, $8.5 \mu$ l nuclease-free water, and $2 \mu$ INA template in each PCR tube. The PCR reaction was conducted using thermocycler (Gene Atlas, Astec, Kasuya, Japan) from a previously described method (Riffon et al., 2001). The PCR reaction conditions were as follows: initial denaturation at $94^{\circ} \mathrm{C}, 1 \mathrm{cycle}$ for $2 \mathrm{~min}$; denaturation at $94^{\circ} \mathrm{C}$ for $45 \mathrm{~s}$; annealing at $58^{\circ} \mathrm{C}, 60.5^{\circ} \mathrm{C}, 60.9^{\circ} \mathrm{C}$, $61.3^{\circ} \mathrm{C}$ (gradient) for $60 \mathrm{~s}$; extension at $72^{\circ} \mathrm{C}$ for 2 min for $35 \mathrm{cycles}$; and a final extension at $72^{\circ} \mathrm{C}$ for $10 \mathrm{~min}$. The amplicons were visualized using $2 \%$ agarose gel (Promega Corporation, Madison, WI, USA). Marker 100 bp Plus DNA ladder was used in this study.

\section{Antimicrobial Susceptibility Testing}

Antimicrobial susceptibility testing of the PCR confirmed $S$. aureus isolates were tested against nine commonly used antimicrobial agents (Abetek, Liverpool, UK) using the Kirby-Bauer disc diffusion method on Mueller Hinton agar (HiMedia, India) following the guidelines of Clinical Laboratory Standards Institute (CLSI) (CLSI, 2012). The isolates were classified in accordance with the guideline of CLSI (CLSI, 2012) as susceptible, intermediate or resistance for each antimicrobials tested according to the manufacturer's instructions by measuring the zone of inhibition around the antimicrobials disc (in millimeter). The details of the nine antimicrobial agents utilized used in this study was shown in Table 1 below. 
Table 1

The list of a panel of antimicrobial agents utilized, their symbols, concentration and break points

\begin{tabular}{|lllll|}
\hline $\begin{array}{l}\text { Antimicrobial } \\
\text { agent (disk code) }\end{array}$ & $\begin{array}{l}\text { Content } \\
(\mu \mathrm{g} / \text { disk) }\end{array}$ & \multicolumn{2}{l|}{$\begin{array}{l}\text { Inhibition zone diameter interpretive criteria } \\
\text { (nearest whole mm) }\end{array}$} \\
\hline & & Susceptible & Intermediate & Resistant \\
\hline Ampicillin (AMP) & $10 \mu \mathrm{g}$ & $\geq 15$ & $12-14$ & $\leq 11$ \\
\hline Chloramphenicol (CHL) & $30 \mu \mathrm{g}$ & $\geq 18$ & $13-17$ & $\leq 12$ \\
\hline Ciprofloxacin (CPR) & $5 \mu \mathrm{g}$ & $\geq 21$ & $16-20$ & $\leq 15$ \\
\hline Cefoxitin (CXT) & $30 \mu \mathrm{g}$ & $\geq 22$ & - & $\leq 21$ \\
\hline Erythromycin (ERY) & $15 \mu \mathrm{g}$ & $\geq 23$ & $14-22$ & $\leq 13$ \\
\hline Gentamicin (GEN) & $10 \mu \mathrm{g}$ & $\geq 15$ & $13-14$ & $\leq 15$ \\
\hline Penicillin (PEN) & $10 \mathrm{units}$ & $\geq 29$ & $21-28$ & $\leq 20$ \\
\hline Streptomycin (STR) & $10 \mu \mathrm{g}$ & $\geq 15$ & $12-14$ & $\leq 11$ \\
\hline Tetracycline (TET) & $30 \mu \mathrm{g}$ & $\geq 19$ & $15-18$ & $\leq 14$ \\
\hline
\end{tabular}

Source: - (CLSI, 2012)

\section{Molecular Detection Of Antimicrobial Resistance Genes}

Polymerase chain reaction amplifications of four antimicrobial resistant genes, which included methicillin resistant gene (mecA), various erythromycin resistant genes (ermA, ermC and $m s r A$ ) were carried out with a pair of specific primers and using previously described protocol (Sawant et al., 2009; Melo et al., 2014) (Table 2). Details of primer sequences, their specific targets and expected amplicon sizes were summarized in Table 2. The reactions were performed in a final volume of $25 \mu$ l each made by $12.5 \mu$ l of 2XTaq PCR Master Mix, $1 \mu \mathrm{l}$ of $10 \mu \mathrm{M}$ primer (each forward and reverse), $3 \mu$ of DNA template and $7.5 \mu \mathrm{l}$ sterile nuclease free water. PCR conditions were described by the original designers of primers (Table 2). Following completion of reactions, PCR products were run on a $1.5 \%$ agarose gel using electrophoresis, stained with gel red at 120 volts for $45 \mathrm{~min}$ and visualized under UV light using a BioDoc-it ${ }^{\mathrm{TM}}$ imaging system (Cambridge, UK). We use 100bp plus DNA marker as molecular marker. 
Table 2

Primers used in this study and the PCR conditions for amplifying some antimicrobial resistant genes

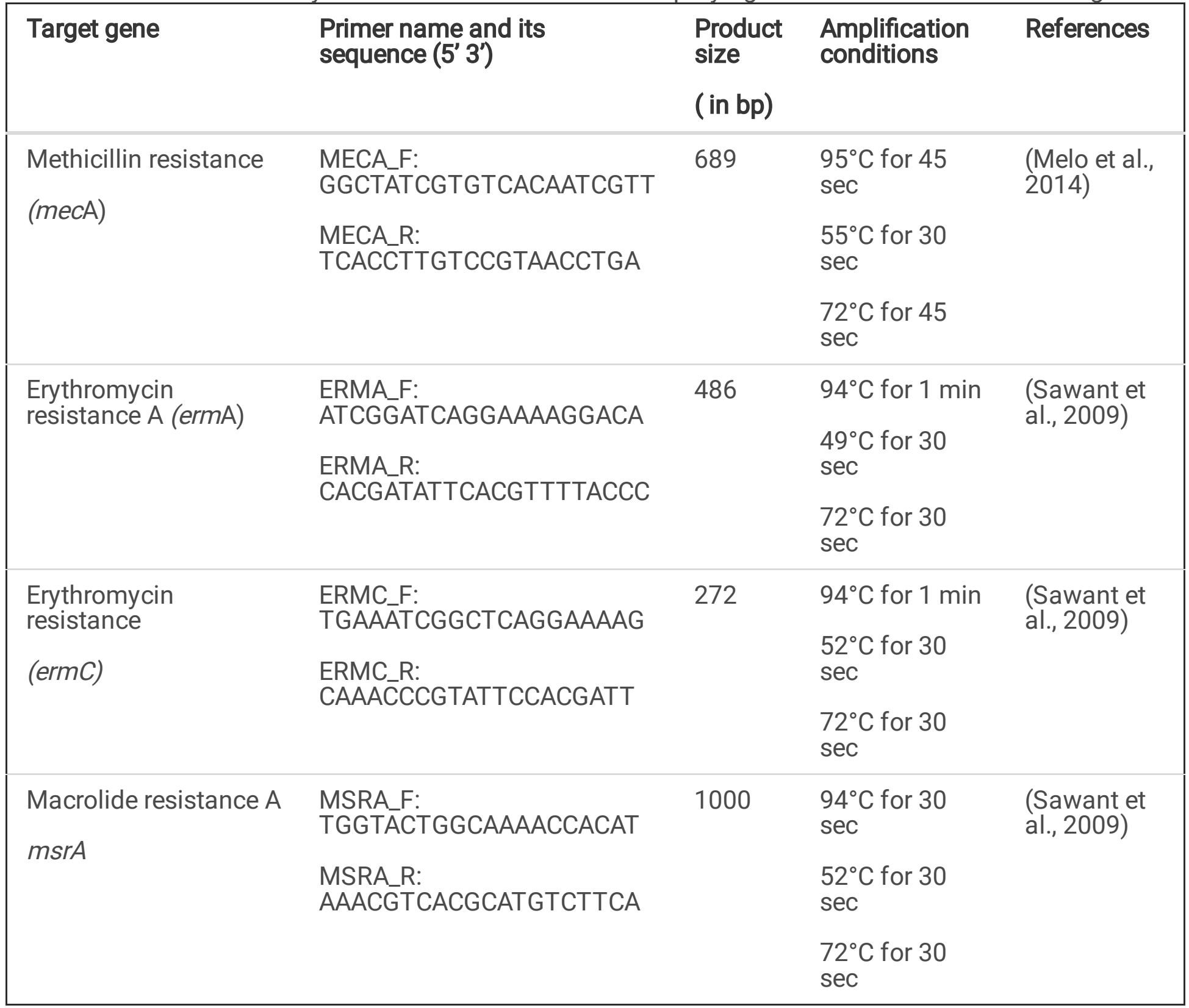

\section{Statistical analysis}

Data generated from the study was arranged, coded and entered to excel spread sheet (Microsoft@ office excels 2010) and subjected to descriptive statistics. The Chi-square test was applied to determine the existence of any association between sampling areas and prevalence of $S$. aureus using 26.0 versions of SPSS. The prevalence of mastitis was calculated by dividing the number of positive animals for CMT to the total number of animals examined times $100 \%$ (Thrusfield, 2005). The significance level was set at Pvalue (0.05) and $95 \%$ confidence level. In all cases, $95 \%$ confidence level and p-value less than 0.05 was consider as statistical significance. 


\section{Results}

\section{Prevalence of bovine subclinical mastitis and $S$. aureus isolates}

A total of 265 lactating dairy cows from various dairy farms from central highland of Ethiopia were screened by using California mastitis test (CMT) for bovine subclinical mastitis. Out of 265 lactating dairy cows screened, 130 (49.06\%, 95\% Cl: 43.08-55.06) of them were found positive by CMT for either of the four quarters. CMT positive milk samples were obtained from different sampling areas which included 54 (61.36\%, 95\% Cl: 38.09-80.39) from the Adaberga, 16 (69.57\%, 95\% Cl: 37.40-89.74) from Ambo and 16 (40\%, 95\%Cl: 17.96-67.00) from Bishoftu and 44 (38.60\%, 95\% Cl: 30.12-47.82) from Holeta. In the present study, the highest and lowest prevalence of bovine subclinical mastitis was recorded samples were collected from Ambo and Holeta with prevalence of $69.57 \%$ and $38.60 \%$, respectively. The prevalence of bovine subclinical mastitis was statistically significant between different sampling areas $\left(X^{2}=15.70 ; P=0.0013\right)$.

On the other hand, 100 (76.92\%, 95\% Cl: 68.79-83.44) milk samples from $130 \mathrm{CMT}$ positive milk samples were tested positive for $S$. aureus based on different biochemical tests and PCR. Figure 2 depicts a gel image with 1267bp PCR gene amplicons demonstrating the presence of the 23SrRNA (S. aureusspecific) gene that was amplified on representative $S$. aureus isolates. $S$. aureus isolates were obtained from different sampling areas, which included 37 (68.52\%, 95\% Cl: 54.80-79.62) from Adaberga, 12 (75\%, 95\% Cl: 47.97-90.71) from Ambo and 16 (100\%) from Bishoftu and 35 (79.55\%, 95\% Cl: 64.80-89.15) from Holeta. Regarding the sampling areas, the highest and lowest recovery rate of $S$. aureus isolates were observed in Bishoftu and Adaberga from CMT positive milk samples, respectively.

\section{Antibiotic Susceptibility Test}

One-hundred $S$. aureus isolates were tested to evaluate their susceptibility patterns a panel of nine antimicrobials agents. In the present study, $S$. aureus isolates were found variably resistant to the antimicrobials tested. Data depicting the susceptibilities of the isolates were presented as percentages are shown in Fig. 3. A large proportion (50-94.6\%) of the S. aureus isolates obtained from Adaberga, Ambo, Bishoftu and Holeta were resistant to ampicillin, cefoxitin, penicillin and streptomycin. Despite the fact that a relatively large proportion (75-83.3\%) of the isolates from Ambo, Bishoftu and Holeta were resistant to streptomycin, on the contrary, only a small proportion (43.24\%) of the isolates from Adaberga sampled were resistant to this antimicrobial agent. Also intermediate sensitivity of $S$. aureus isolates was highest towards Erythromycin (50\%), Ciprofloxacillin (35\%) and followed by Gentamycin (24\%) and Streptomycin (14\%). Moreover, isolates obtained from Ambo were relatively highly susceptible to ciprofloxacillin and gentamycin. Similarly, low level resistance was observed against chloramphenicol as summarized in Table 3. 
Table 3: Prevalence of drug resistant $S$. aureus isolates from various sampling sites

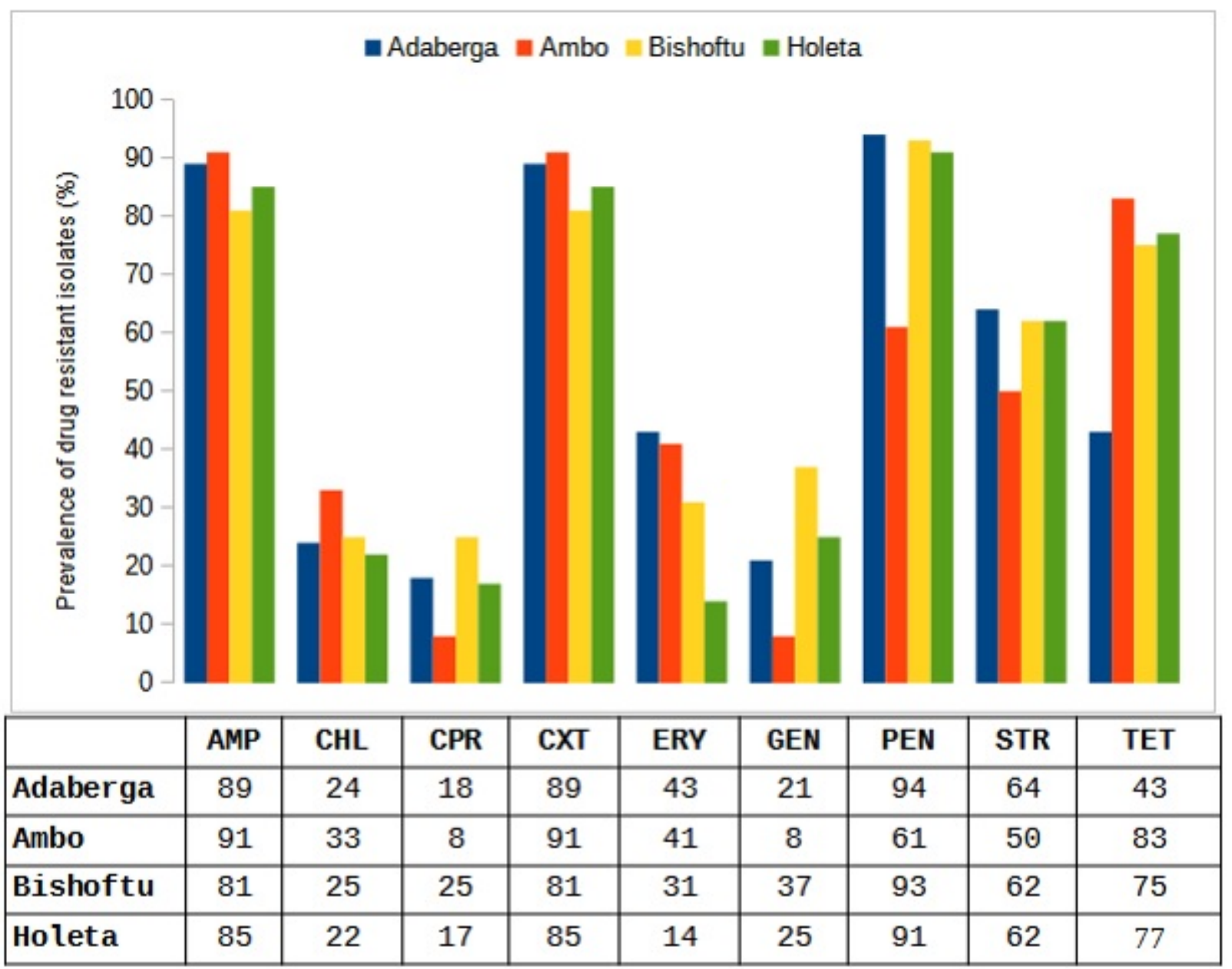

Similarly, multi-drug resistance (MDR) patterns were generated from $100 \mathrm{~S}$. aureus isolates showing resistance to three or more antibiotics according to (Coyle, 2005). The MDR pattern PEN-AMP-CXT-TETGEN was observed in $45 \%$ of the isolates from Adaberga and in $42 \%$ of Ambo isolates. The MDR pattern PEN-AMP-CXT was dominant among $27 \%, 22 \%$ and $26 \%$ of Adaberga and Bishoftu and Holeta samples, respectively. The predominant MDR pattern for isolates from Bishoftu and Holeta were PEN-AMP-CXTSTR-TET and PEN-AMP-CXT-STR was obtained at 33 and 24\%, respectively. These results indicate that in the present study, MDR $S$. aureus was isolated from milk samples.

Table 4: Antimicrobial resistance patterns of Staphylococcus aureus isolates from various sampling sites 


\begin{tabular}{|c|c|c|c|c|}
\hline \multirow{2}{*}{$\begin{array}{l}\text { Jampling } \\
\text { ırea }\end{array}$} & \multirow{2}{*}{$\begin{array}{l}\text { Number of } \\
\text { isolates }\end{array}$} & \multirow[b]{2}{*}{$\begin{array}{l}\text { Antibiotic resistance } \\
\text { patterns }\end{array}$} & \multicolumn{2}{|c|}{ Multidrug resistance } \\
\hline & & & Number & Percentage \\
\hline \multirow{4}{*}{ Adaberga } & \multirow{4}{*}{11} & PEN-AMP-CXT & 3 & 27 \\
\hline & & PEN-AMP-CXT-TET & 1 & 9 \\
\hline & & PEN-AMP-CXT-TET-GEN & 5 & 45 \\
\hline & & PEN-AMP-CXT-TET-GEN & 3 & 42 \\
\hline \multirow[t]{2}{*}{ Ambo } & 7 & PEN-AMP-TET-STR & 1 & 14 \\
\hline & & PEN-AMP-CXT & 2 & 22 \\
\hline \multirow[t]{4}{*}{ 3ishoftu } & 9 & PEN-AMP-CXT-STR & 1 & 11 \\
\hline & & PEN-AMP-CXT-STR-TET & 3 & 33 \\
\hline & & PEN-AMP-CXT & 4 & 26 \\
\hline & & PEN-AMP-CXT-STR & 6 & 24 \\
\hline \multirow[t]{2}{*}{ Holeta } & 15 & PEN-AMP-CXT-STR-TET & 3 & 20 \\
\hline & & PEN-AMP-CXT-TET & 1 & 6 \\
\hline
\end{tabular}

\section{Discussion}

The overall cow-level apparent prevalence of bovine subclinical mastitis in the central highland of Ethiopia was $49.05 \%$ (130/265). This result was almost in agreement with findings from similar studies by Ayana et al. (2017) from Bishoftu, Arga et al. (2012) from Ambo, Dego and Tareke (2003) from southern Ethiopia and Mungube et al. (2004) from Addis Ababa, which reported prevalence of $46.09 \%$, $58.82 \%, 40.4 \%$ and $39.8 \%$, respectively. However, the result of the present study was lower than the reports of Duguma et al. (2014) who reported a prevalence of bovine subclinical mastitis was $81 \%$ in Holeta, central highland of Ethiopia, Bishi (1998) who reported $69.8 \%$ in dairy farms of Addis Ababa and its vicinity and Mekibib et al. (2010) who reported 74.7\% around Addis Ababa. Moreover, the present finding was higher than previous reports by Workineh et al. (2002) who reported a prevalence of $25.1 \%$ in Addis Ababa and Delesse (2010) who reported a 10.3\% with prevalence of mastitis in dairy farms around Holeta town, Ethiopia. As mastitis is a complex disease, the difference of prevalence observed from the current study could be due to interactions of various factors such as dairy cow management system and husbandry practice, environmental conditions, animal risk factors and virulence factors of the circulating causative agents (Radositis et al., 2007) and also difference in study methods used, period of investigation and specific farm-level intervention might contribute in the variation of the prevalence of mastitis.

According to the biochemical tests and PCR finding in this study, 79.92\% (100/130) of S. aureus isolates were recovered from $130 \mathrm{CMT}$ positive milk samples. The finding of the current study was higher than the previous findings which were done around Sebeta (44.03\%) by Sori et al. (2005), in Holeta agricultural research centre (43.3\%) by Duguma et al. (2014), in and around Holeta town (47.1\%) by Mekibib et al. 
(2010) and in Bishoftu area (39.5\%) by Asrat et al. (2013). This high rate of S. aureus in this study might suggest the high rate transmission of $S$. aureus infection which might occurred because of poor hygienic conditions during milking process in which contamination with $S$. aureus might occurred from contaminated milker's hands and milking equipment (Radositis et al., 2007). Apart from Ethiopia, $S$. aureus has also been reported as the chief etiological agent of mastitis in cattle by many studies from African and Asian countries (Abebe et al., 2016). Though direct comparisons among studies might be difficult, but in general, the variation in the prevalence between the present and previous studies might be due to differences in detection methods, geographical location of the study sites and differences in farm management practices in each studied farms. .

Previous studies have revealed that an increasing trend towards the occurrence of $S$. aureus isolates that portray multiple antimicrobials resistance phenotypes (Normanno et al., 2007; Pesavento et al., 2007) ; hence, $S$. aureus isolates that harbour multiple antimicrobials resistant traits have been reported to negatively impact on the treatment of staphylococcal infections. The present study showed a higher level of resistance of S. aureus to penicillin (93\%), ampicillin (87\%), tetracycline (75\%) and cefoxitin (87\%). The current finding was in line with the findings of Abebe et al. (2016) who reported resistance of $S$. aureus to penicillin (94\%), tetracycline (73.8\%) around Addis Ababa and (Abera et al., 2013) who recorded $94.4 \%$ to penicillin around Adama and Sori et al. (2005) who recorded $87.2 \%$ S. aureus isolates were found to be resistant to penicillin. In general, the current study able to show that susceptibility of $S$. aureus to commonly used antimicrobials, penicillin, ampicillin, cefoxtin and tetracycline in study area was very low. The possible justification for this could be the development of alarming level of resistance of $S$. aureus due to the regular use of these commonly used antibiotics for the treatment of cows that might resulted in the spread of resistant strain in study area. This result was in accordance with reports from earlier studies in other countries, suggesting a possible development of resistance from prolonged and indiscriminate usage of some antimicrobials (Enright et al., 2002). Previous report indicated that the prevalence of antimicrobials resistance in $S$. aureus isolates become a serious problem in a dairy herds (WANG et al., 2009).The over-use of antibiotics in dairy farms is one of the major factors responsible for the emergence of drug resistant bacteria. Furthermore, isolates that are resistant to ampicillin may cross select for resistance to other beta-lactams including penicillin, therefore, resistance to ampicillin is an indication of the resistance of the isolates to other beta-lactam antibiotics (WANG et al., 2009). Methicillin-resistant Staphylococcus aureus (MRSA) is currently a major burden in veterinary and human medicine (Tangka et al., 2002). This type of resistance is considered to be one of the most important and has been implicated in many animal and human illnesses that have resulted in high mortality. It is therefore, very important to implement a systemic application of an in vitro antibiotic susceptibility test prior to the use of antibiotics in both treatment and prevention of intra-mammary infections.

In the present study, multiple drug resistant (MDR) S. aureus strains defined as isolates that were resistant to three or more antibiotics were obtained in $54.26 \%$ of some of the milk samples analyzed. Development of multiple antibiotic resistances among most of these isolates may be attributed to transmission of resistance (R-factor) which is a plasmid-mediated genetic determinant. S. aureus often contain multiple plasmids that may contain various numbers of antibiotic resistant genes (Yamamoto et 
al., 2013). Given the fact that antibiotic resistance traits in bacteria species including $S$. aureus may occur either spontaneously by mutation and selection or by acquisition of new genetic material from other resistant organisms through transformation, transduction and conjugation it is usually not surprising that the antibiotic resistance profiles of isolates from the same region may vary considerably.

In the present study, the isolates of $S$. aureus were tested for four antimicrobial resistance genes which included methicillin resistance gene (mecA), various erythromycin resistance genes (ermA, ermC) and macrolide resistance A gene ( $\mathrm{msr}$ ) . Among the four antimicrobial resistance genes screened, only mecA gene was amplified, $12 \%(12 / 100)$ of $S$. aureus isolates out of $100 \mathrm{~S}$. aureus isolates and other antimicrobial resistance genes which included ermA, ermC and msrA were not detected in any of the isolates in the present study. In this study, mecA positive $S$. aureus was detected in milk samples collected from different sampling areas, including Ambo 16.67\% (2/12), Bishoftu 25\% (3/12) and Holeta $53.33 \%(7 / 12)$ based on the presence of the mecA gene amplicon. However, the present study was disagree with the report from the Central highlands of Ethiopia by Seyoum et al. (2016) and (Mekonnen et al., 2018) from North-West Ethiopia, who did not detect any mecA positive $S$. aureus in their study. Variation in the proportion of mecA positive $S$. aureus in comparison to other researcher might be due to the difference in sample size, antibiotic use in animal husbandry and hygiene practices among the dairy farms.

The mecA gene was detected in some isolates that resist cefoxitin. The existence of mecA positive cefoxitin resistance $S$. aureus in milk has been reported in many previous studies (UGWU et al., 2015). The presence of mecA-positive MRSA strains in bovine milk samples has been reported in many countries (Kreausukon et al., 2012). The presence of mecA negative MRSA strains in bovine milk samples has also been reported by (Kumar et al., 2011). However, mecA-negative cefoxitin resistance $S$. aureus has been also recovered from bovine milk; the resistance revealed by mecA-negative cefoxitin resistance $S$. aureus isolates might be attributed to the presences of other beta-lactam resistance mechanisms (Malik et al., 2007). This indicated the presence of incompatibility between the detection of methicillin resistance phenotypically using cefexitin discs and the absence of mecA gene in some MRSA isolates. This finding is in accordance with (García-Álvarez et al., 2011) who identified phenotypic MRSA isolates without mecA gene. This may be attributed to the presence of PCR inhibitors or other physical factors that may have compromised the sensitive of PCR in the detection of $m e c A$ gene.

\section{Conclusion}

The present study has revealed that bovine mastitis is a widely prevalent disease in the dairy farms of the central Ethiopia. The present investigation also explored that $S$. aureus is an important cause for bovine mastitis, which warns the higher public health risk due to consumption of raw milk and its products. The study also demonstrated that isolates are characterized by multiple drug resistance to commonly prescribed drugs in veterinary and human pharmacies. Dairy cows in the study area had high rates of infection by multi-drug resistant $S$. aureus isolates, especially methicillin resistance A ( $m e c A)$ gene which may hold a serious threat to human and animal health. Though the development of antimicrobial 
resistant determinants in $S$. aureus is associated with the uncontrolled usage of antimicrobial agents in human and veterinary medicine, the incidence of drug-resistant $S$. aureus in bovine milk samples warrants closer monitoring. Therefore, careful monitoring for the resistance status is an utmost need since the transmission of this pathogen is dynamic and involves human, animals, and likely the farm production environment.

\section{List Of Abbreviations}

$\mathrm{AMP}=$ Ampicillin; $\mathrm{CHL}=$ Chloramphenicol; $\mathrm{CPR}=$ Ciprofloxacillin; $\mathrm{CXT}=$ Cefoxitin; $\mathrm{ERY}=$ Erythromycin; GEN = Gentamycin; PEN = Penicillin; STR = Streptomycin; TET = Tetracycline; CMT = California mastitis test; $\mathrm{MDR}=$ Multi-drug resistance, $\mathrm{DNA}=$ Deoxyribonucleic acid; $\mathrm{P}$-value = predictive value; $\mathrm{PCR}=$ polymerase chain reaction; $\chi 2$ = chi-square; MRSA = Methicillin-resistant Staphylococcus aureus

\section{Declarations}

\section{Ethics approval and consent to participate}

This study was conducted after gaining full approval by the ethical review board of the College of Veterinary Medicine and Agriculture, Addis Ababa University, Ethiopia. Informed written consent was taken from all participants prior to participation in this study. Also, permission from dairy farm owners/managers was obtained before collection of milk samples

\section{Consent for publication}

Not applicable

\section{Competing interests}

The authors declare that they have no competing interests

\section{Funding}

This study was supported by Ethiopian Institute Agricultural Research and Addis Ababa University. The institutions had no role on design of the study and collection, analysis and interpretation of data and in writing the manuscript.

\section{Acknowledgments}

Authors greatly appreciate the contribution made by Ethiopian Institute Agricultural Research, National Agricultural Biotechnology Research Center in funding this project and the staff of the Animal Biotechnology Research Program for assisting during the bench work which has led to the success of this study. We thankful to the farmers and veterinarians who provided the milk samples used in this study. 


\section{References}

Abebe, R., Hatiya, H., Abera, M., Megersa, B., Asmare, K., 2016. Bovine mastitis: prevalence, risk factors and isolation of Staphylococcus aureus in dairy herds at Hawassa milk shed, South Ethiopia. BMC veterinary research 12,270 .

Abera, B., Lemma, D., Iticha, I., 2013. Study of bovine mastitis in asella government dairy farm of Oromia Regional state, South Eastern Ethiopia. International journal of current research and academic review 1, 134-145.

Arga, S., Tadesse, G., Tessema, T.S., Zewdu, E., 2012. Bacterial pathogens and udder infection dynamics during the early lactation period in primiparous cows in Ambro Town, Central Ethiopia. Global Veterinaria 8, 403-408.

Asrat, A.M.D., Woldeamanuel, Y., Tefera, G., 2013. Identification and antimicrobial susceptibility of Staphylococcus aureus isolated from milk samples of dairy cows and nasal swabs of farm workers in selected dairy farms around Addis Ababa, Ethiopia. African Journal of Microbiology Research 7, 35013510 .

Ayana, H.W., Mekonnen, B.T., Bulle, A.S., Berecha, M.S., 2017. Isolation and identification of methicillinresistant Staphlococcus aureus from mastitic dairy cows in Bishoftu town, Ethiopia. African Journal of Microbiology Research 11, 1606-1613.

Barkema, H., Schukken, Y., Zadoks, R., 2006. Invited review: The role of cow, pathogen, and treatment regimen in the therapeutic success of bovine Staphylococcus aureus mastitis. Journal of dairy science $89,1877-1895$.

Bishi, A.S., 1998. Cross-sectional and longitudinal prospective study of bovine clinical and subclinical mastitis in periurban and urban dairy production systems in the Addis Ababa region, Ethiopia.

CLSI, C., 2012. M100-S25: Performance Standards for Antimicrobial Susceptibility Testing. Twenty-Fifth Informational Supplement.

Coyle, M.B., 2005. Manual of antimicrobial susceptibility testing. BCIT Imaging Services.

Dego, O.K., Tareke, F., 2003. Bovine mastitis in selected areas of southern Ethiopia. Tropical animal health and production $35,197-205$.

Duarte, C.M., Freitas, P.P., Bexiga, R., 2015. Technological advances in bovine mastitis diagnosis: an overview. Journal of veterinary diagnostic investigation $27,665-672$.

Duguma, A., Tolosa, T., Yohannes, A., 2014. Prevalence of clinical and sub-clinical mastitis on cross bred dairy cows at Holleta Agricultural Research Center, Central Ethiopia. Journal of Veterinary Medicine and Animal Health 6, 13-17. 
Enright, M.C., Robinson, D.A., Randle, G., Feil, E.J., Grundmann, H., Spratt, B.G., 2002. The evolutionary history of methicillin-resistant Staphylococcus aureus (MRSA). Proceedings of the National Academy of Sciences 99, 7687-7692.

Gao, J., Ferreri, M., Yu, F., Liu, X., Chen, L., Su, J., Han, B., 2012. Molecular types and antibiotic resistance of Staphylococcus aureus isolates from bovine mastitis in a single herd in China. The Veterinary Journal 192, 550-552.

García-Álvarez, L., Holden, M.T., Lindsay, H., Webb, C.R., Brown, D.F., Curran, M.D., Walpole, E., Brooks, K., Pickard, D.J., Teale, C., 2011. Meticillin-resistant Staphylococcus aureus with a novel mecA homologue in human and bovine populations in the UK and Denmark: a descriptive study. The Lancet infectious diseases 11, 595-603.

Gussmann, M., Steeneveld, W., Kirkeby, C., Hogeveen, H., Farre, M., Halasa, T., 2019. Economic and epidemiological impact of different intervention strategies for subclinical and clinical mastitis. Preventive veterinary medicine $166,78-85$.

Heikkilä, A.-M., Liski, E., Pyörälä, S., Taponen, S., 2018. Pathogen-specific production losses in bovine mastitis. Journal of dairy science 101, 9493-9504.

Hu, Y., Gao, G.F., Zhu, B., 2017. The antibiotic resistome: gene flow in environments, animals and human beings. Frontiers of Medicine 11, 161-168.

Kadlec, K., Entorf, M., Peters, T., 2019. Occurrence and characteristics of livestock-associated methicillinresistant Staphylococcus aureus in quarter milk samples from dairy cows in Germany. Frontiers in microbiology 10, 1295.

Kreausukon, K., Fetsch, A., Kraushaar, B., Alt, K., Müller, K., Krömker, V., Zessin, K.-H., Käsbohrer, A., Tenhagen, B.-A., 2012. Prevalence, antimicrobial resistance, and molecular characterization of methicillinresistant Staphylococcus aureus from bulk tank milk of dairy herds. Journal of dairy science $95,4382-$ 4388.

Kumar, R., Yadav, B., Singh, R., 2011. Antibiotic resistance and pathogenicity factors in Staphylococcus aureus isolated from mastitic Sahiwal cattle. Journal of biosciences $36,175-188$.

Malik, S., Christensen, H., Peng, H., Barton, M.D., 2007. Presence and diversity of the $\beta$-lactamase gene in cat and dog staphylococci. Veterinary microbiology $123,162-168$.

Marama, A., Mamu, G., Birhanu, T., 2016. Prevalence and antibiotic resistance of Staphylococcus aureus mastitis in Holeta area, Western Ethiopia. Global Veterinaria 16, 365-370.

Mekibib, B., Furgasa, M., Abunna, F., Megersa, B., Regassa, A., 2010. Bovine mastitis: Prevalence, risk factors and major pathogens in dairy farms of Holeta Town, Central Ethiopia. Veterinary World 3, 397403. 
Mekonnen, S., Lam, T., Hoekstra, J., Rutten, V.P., Tessema, T., Broens, E., Riesebos, A., Spaninks, M., Koop, G., 2018. Characterization of Staphylococcus aureus isolated from milk samples of dairy cows in small holder farms of North-Western Ethiopia. BMC veterinary research 14, 246.

Melo, D.A.d., Coelho, I.d.S., Motta, C.C.d., Rojas, A.C.C.M., Dubenczuk, F.C., Coelho, S.d.M.d.O., Souza, M.M.S.d., 2014. Impairments of mecA gene detection in bovine Staphylococcus spp. Brazilian Journal of Microbiology 45, 1075-1082.

Mungube, E., Tenhagen, B.-A., Kassa, T., Regassa, F., Kyule, M., Greiner, M., Baumann, M., 2004. Risk factors for dairy cow mastitis in the central highlands of Ethiopia. Tropical Animal Health and Production $36,463-472$.

Normanno, G., Corrente, M., La Salandra, G., Dambrosio, A., Quaglia, N., Parisi, A., Greco, G., Bellacicco, A., Virgilio, S., Celano, G., 2007. Methicillin-resistant Staphylococcus aureus (MRSA) in foods of animal origin product in Italy. International journal of food microbiology 117, 219-222.

Perez-Roth, E., Claverie-Martın, F., Villar, J., Mendez-Alvarez, S., 2001. Multiplex PCR for Simultaneous Identification ofStaphylococcus aureus and Detection of Methicillin and Mupirocin Resistance. Journal of clinical microbiology 39, 4037-4041.

Pesavento, G., Ducci, B., Comodo, N., Nostro, A.L., 2007. Antimicrobial resistance profile of Staphylococcus aureus isolated from raw meat: A research for methicillin resistant Staphylococcus aureus (MRSA). Food control 18, 196-200.

Quinn, P.J., Markey, B.K., Leonard, F., FitzPatrick, E., Fanning, S., 2015. Concise review of veterinary microbiology. John Wiley \& Sons.

Radositis, O., Gay, C., Hinchcliff, K., Constable, P., 2007. Veterinary medicine. A textbook of the diseases of cattle, horses, sheep, pigs and goats. Saunders Elsevier. Oxford (UK).

Radostits, O.M., Gay, C., Hinchcliff, K.W., Constable, P.D., 2007. A textbook of the diseases of cattle, horses, sheep, pigs and goats. Veterinary medicine 10, 2045-2050.

Riffon, R., Sayasith, K., Khalil, H., Dubreuil, P., Drolet, M., Lagacé, J., 2001. Development of a rapid and sensitive test for identification of major pathogens in bovine mastitis by PCR. Journal of clinical microbiology 39, 2584-2589.

Saini, V., McClure, J., Scholl, D.T., DeVries, T.J., Barkema, H.W., 2013. Herd-level relationship between antimicrobial use and presence or absence of antimicrobial resistance in gram-negative bovine mastitis pathogens on Canadian dairy farms. Journal of Dairy Science 96, 4965-4976.

Sawant, A., Gillespie, B., Oliver, S., 2009. Antimicrobial susceptibility of coagulase-negative Staphylococcus species isolated from bovine milk. Veterinary microbiology 134, 73-81. 
Seyoum, E.T., Mekonene, T.K., Woldetsadik, D.A., Zewudie, B.M., Gebreyes, W.A., 2016. Enterotoxin gene profile of Staphylococcus aureus isolates recovered from bovine milk produced in central Ethiopia. The Journal of Infection in Developing Countries 10, 138-142.

Song, M., Bai, Y., Xu, J., Carter, M.Q., Shi, C., Shi, X., 2015. Genetic diversity and virulence potential of Staphylococcus aureus isolates from raw and processed food commodities in Shanghai. International journal of food microbiology 195, 1-8.

Sori, H., Zerihun, A., Abdicho, S., 2005. Dairy cattle mastitis in and around Sebeta, Ethiopia. Journal of Applied Research in Veterinary Medicine 3, 332.

Tangka, F.K., Emerson, R.D., Jabbar, M.A., 2002. Food security effects of intensified dairying: Evidence from the Ethiopian highlands. ILRI (aka ILCA and ILRAD).

UGWU, I.C., ANYANWU, M.U., UGWU, C.C., OKORO, J.C., 2015. Isolation and detection of methicillinresistant staphylococci in healthy broilers in Nsukka Southeast, Nigeria. Notulae Scientia Biologicae 7, 20-25.

Wald, R., Hess, C., Urbantke, V., Wittek, T., Baumgartner, M., 2019. Characterization of Staphylococcus species isolated from bovine quarter milk samples. Animals 9, 200.

WANG, F., ZHU, D.-m., HU, F.-p., RUAN, F.-y., NI, Y.-x., SUN, J.-y., XU, Y.-c., ZHANG, X.-j., HU, Y.-j., Al, X.-m., 2009. CHINET 2008 surveillance of bacterial resistance in China [J]. Chinese Journal of Infection and Chemotherapy 5 .

Workineh, S., Bayleyegn, M., Mekonnen, H., Potgieter, L., 2002. Prevalence and aetiology of mastitis in cows from two major Ethiopian dairies. Tropical Animal Health and Production 34, 19-25.

Xavier, A., Almeida, A., Souza, C., Silva, L., Ruas, A., Sanglard, D., Júnior, A., Oliveira, A., Xavier, M., 2017. Phenotypic and genotypic characterization of Staphylococcus aureus isolates in milk from flocks diagnosed with subclinical mastitis. Genet. Mol. Res 16, 1-11.

Yamamoto, T., Hung, W.-C., Takano, T., Nishiyama, A., 2013. Genetic nature and virulence of communityassociated methicillin-resistant Staphylococcus aureus. BioMedicine 3, 2-18.

\section{Figures}




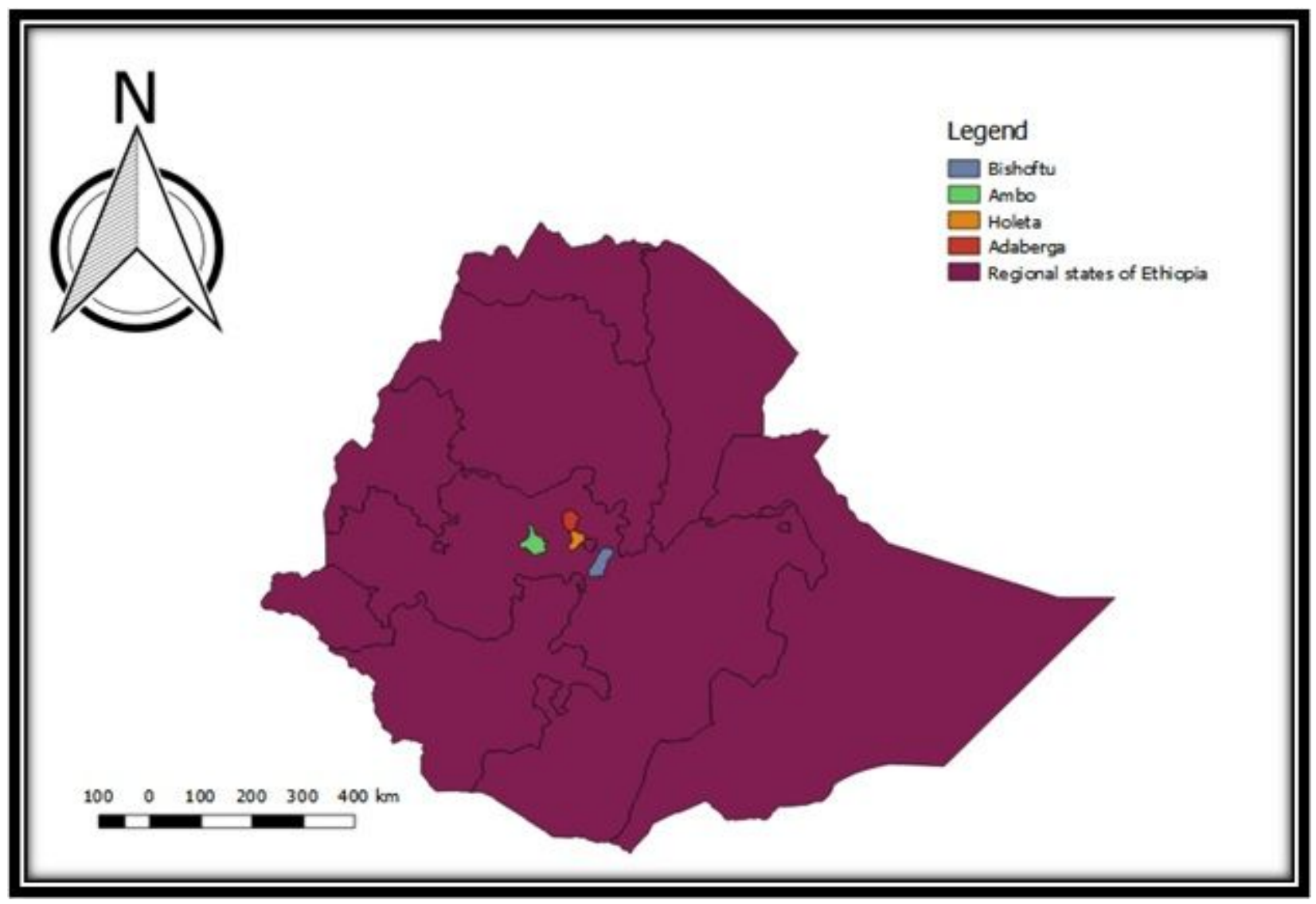

Figure 1

Map of Ethiopia indicating study areas of the research. Specific sampling areas are indicated in different colors that are explained in the legend.

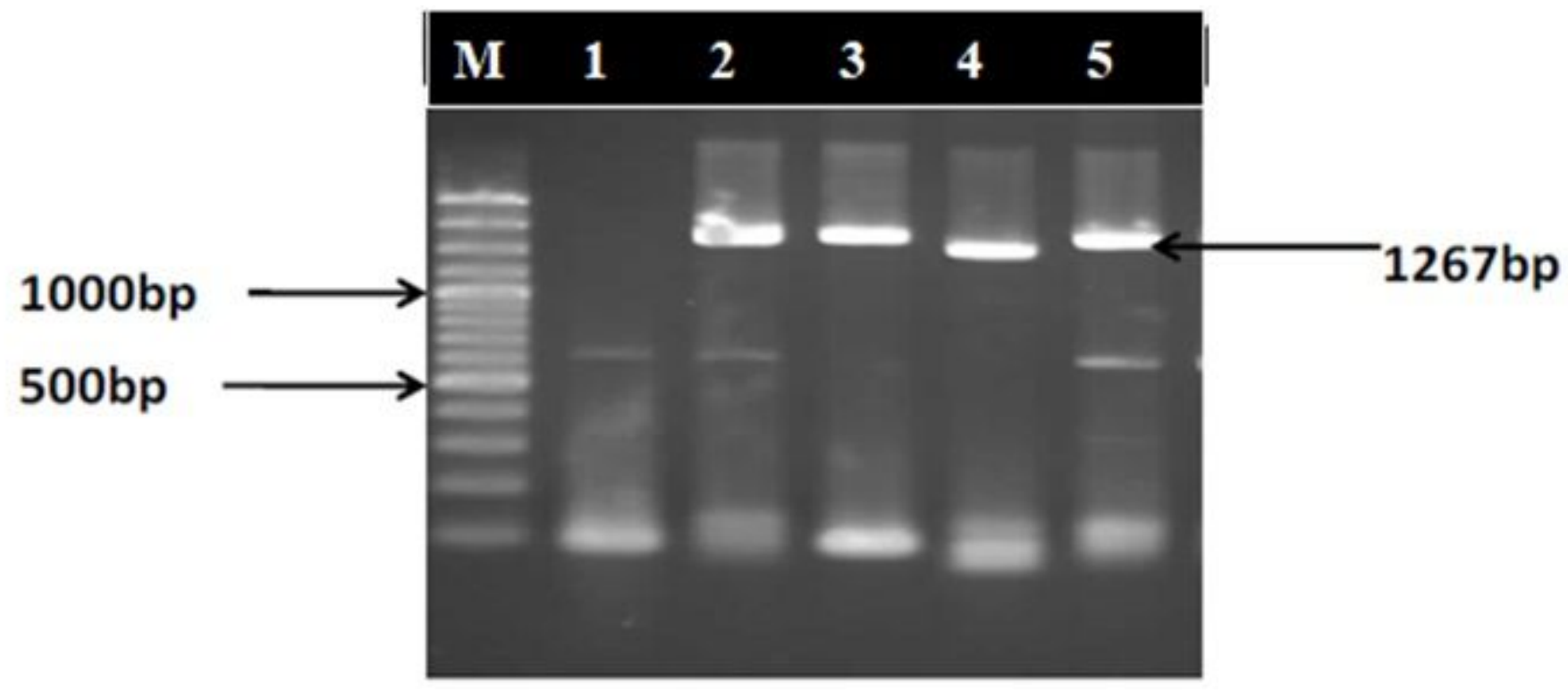

Figure 2

Amplicons of the 23SrRNA gene of representative S. aureus with a size of $1267 \mathrm{bp}$. Lane $\mathrm{M}$ is a $100 \mathrm{bp}$ plus DNA marker (DNA ladder, BioBasic); lanes 1 to 5 are test samples 


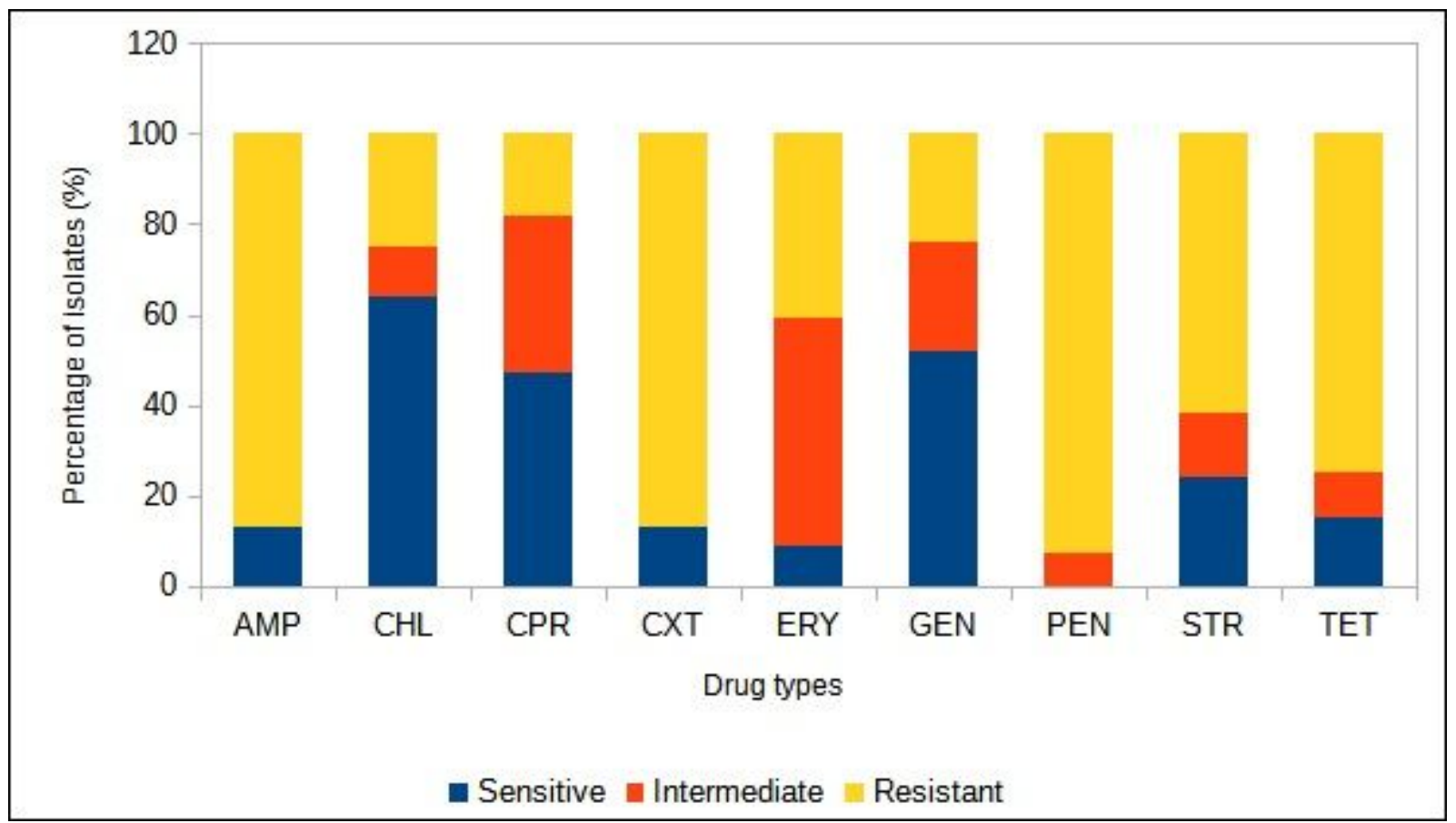

Figure 3

Antimicrobial resistance patters of S. aureus isolates

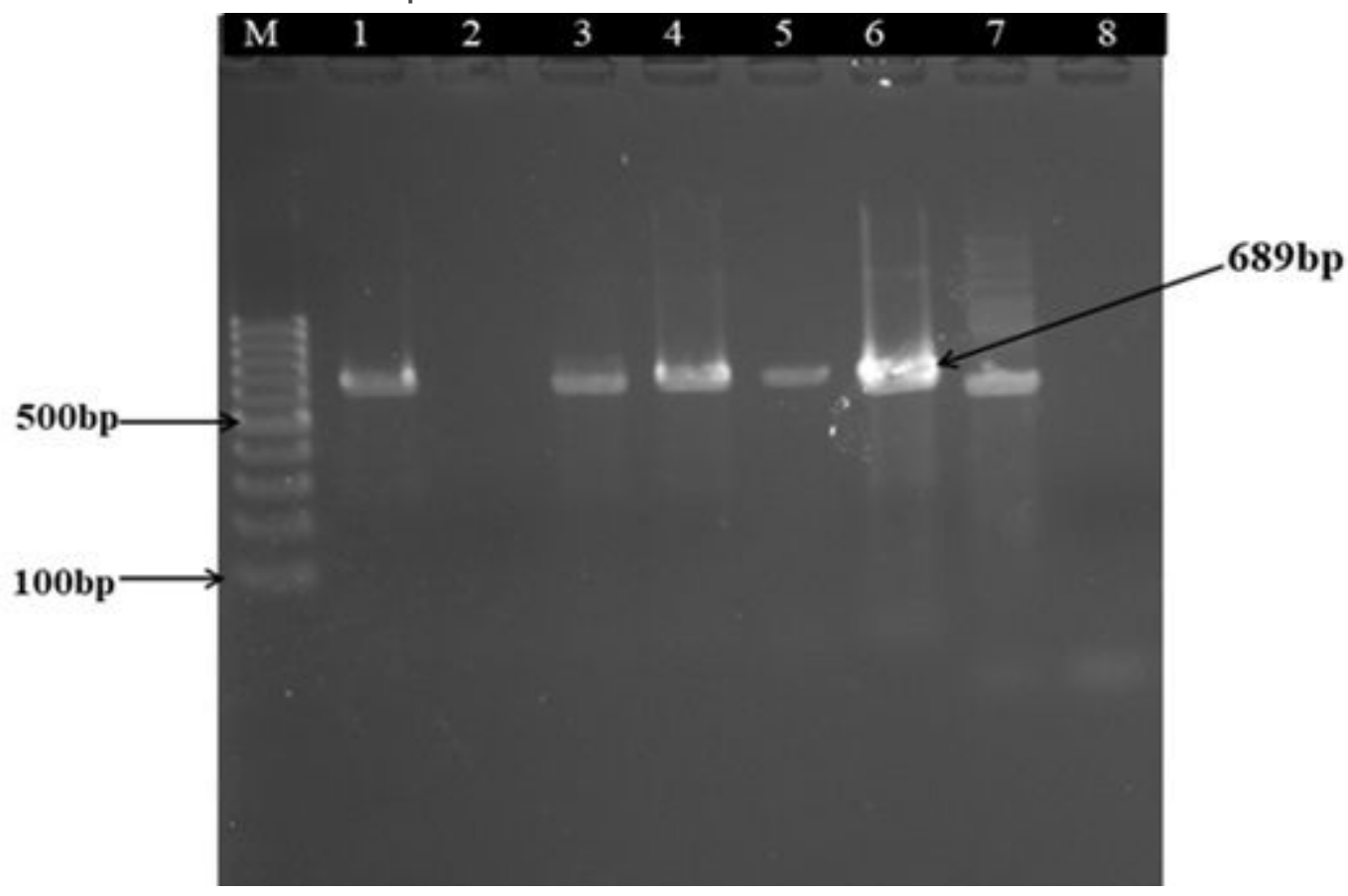

Figure 4

Agarose gel electrophoresis analysis for the mecA gene in S. aureus isolates, Lane $\mathrm{M}=100 \mathrm{bp}$ DNA marker, Lanes 1-7 = test samples 


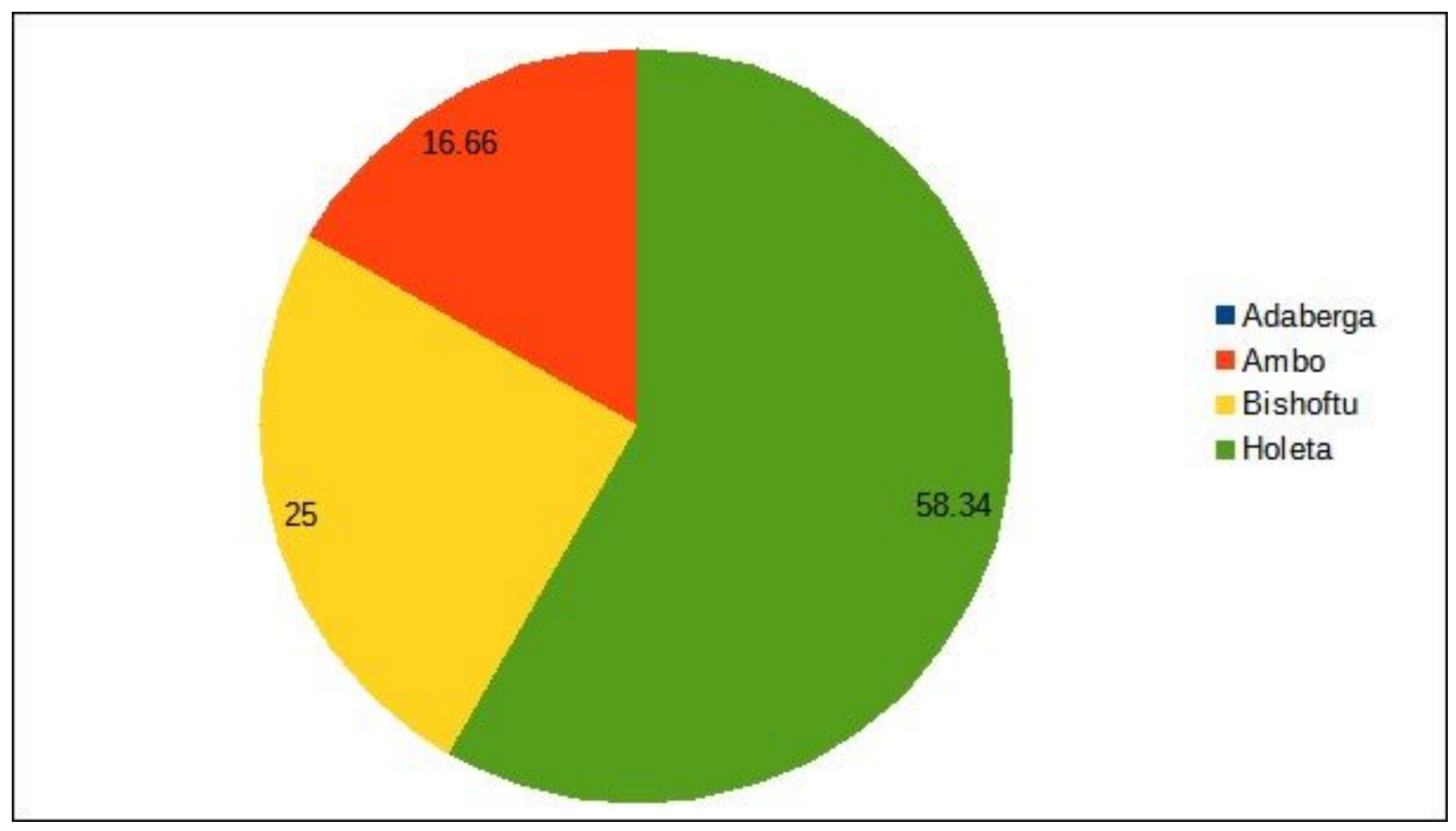

Figure 5

Prevalence of S. aureus isolates that were positive for the targeted genes from sampling areas 